\title{
Modelling of grazing systems at the farm level
}

\author{
John Milne*, Alan Sibbald \\ Macaulay Land Use Research Institute, Craigiebuckler, Aberdeen AB 15 8QH, UK
}

(Received 17 June 1998; accepted 24 August 1998)

\begin{abstract}
A simplified description of a model of a grazing system suitable for implementation at the geographical scale of the field or farm is described. The progress that has been made in the modelling of the soil, plant and animal processes within grazing systems is described and research areas are identified where improvements in understanding are needed. Arguments are presented for the importance of developing grazing models at the farm scale and incorporating them into decision support tools to aid research on rural land use and to provide support in decision-making by farmers, and regional and local government. Two examples of farm-scale decision support tools, HILLPLAN and LADSS, are described which will aid respectively tactical and strategic decision-making at the farm scale. (CElsevier/Inra
\end{abstract}

\section{decision support tools / animal production / vegetation dynamics / grassland ecosystems}

Résumé - Modélisation de systèmes de pâturage pour l'exploitation agricole. Le modèle d'un système de pâturage mis en œuvre à l'échelle géographique de la parcelle ou de l'exploitation agricole est décrit. Les progrès accomplis dans la modélisation des processus biologiques du sol, des plantes et des animaux dans les systemes pâturés sont également exposés et les domaines de recherches dans lesquels une amélioration des connaissances est nécessaire sont identifiés. Des arguments sont présentés pour souligner l'importance de développer des modèles de pâturage à l'échelle de l'exploitation et de les associer aux outils d'aide à la décision pour faciliter la recherche sur l'utilisation des territoires ruraux et fournir un support d'aide à la décision pour les exploitants et les gouvernements régionaux et locaux. Deux exemples d'outils d'aide à la décision à l'échelle de l'exploitation, HILLPLAN et LADSS, sont décrits ; ils faciliteront, respectivement, la prise de décision tactique et stratégique au niveau de l'exploitation. OElsevier / Inra

outils d'aide à la décision / production animale / dynamique de la végétation / écosystème prairial

\footnotetext{
* Correspondence and reprints

Tel.: (44) 01224318611 ; fax: (44) 0122431 15 56; e-mail: j.milne@mluri.sari.ac.uk
} 


\section{INTRODUCTION}

Grazing systems are complex and involve a large number of processes; some of them with important feed-backs. In the past 15 years a considerable amount of understanding of and data on grazing processes in temperate grasslands has been obtained through detailed experimentation across a number of scientific disciplines [23]. Over the same period there have also been developments in conceptual modelling and in computer software. Advances in these areas have led to the building of computer-based models which simulate grazing systems. Figure 1 shows a flow diagram of a simplified version of a grazing model which can be used to describe the main features of a grazing system relevant to a number of geographical scales from the field to the farm. It demonstrates the key processes of plant production and offtake by animals, which determine dietary choice and herbage intake or its corollary, herbage offtake, and hence utilisation rate of the herbage.

The multiple objectives that now exist for many grazing systems in Europe, for example agricultural output and nature con- servation value, are also reflected in figure 1. Whilst the prediction of the output of animal products has been a feature of several models, the impact of the grazing animal on vegetation dynamics, and its prediction from utilisation rate, has not been attempted for other than simple mixtures of species. Figure I also describes the major feedbacks of herbivory on plant growth. Illius and Hodgson [16] have argued that, whilst understanding of processes in grassland ecosystems has increased considerably, developments in their management have been relatively slow and often empirical in their nature. This is also reflected in the development of models.

The aim of this paper is: 1) to demonstrate the progress that has been made in the modelling of grazing systems; 2) to argue the importance of developing grazing models at the farm scale; and 3) to illustrate two approaches (one a tactical decision support tool, HILLPLAN, and the other a strategic farm planning tool involving grazing systems, LADSS) to providing decision support to farmers and regional and government departments.

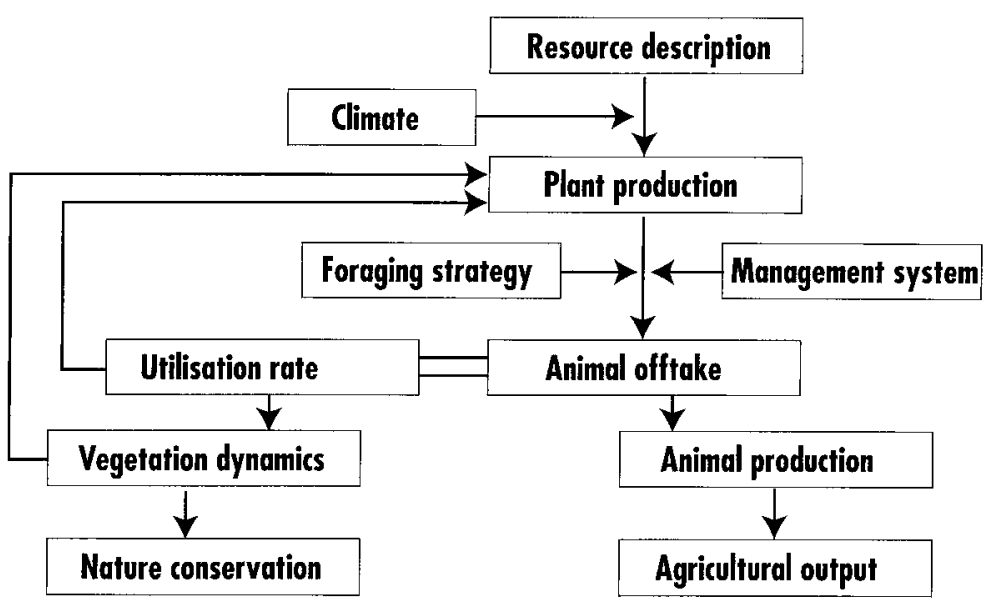

Figure 1. Diagrammatic representation of a model of a grazing system appropriate for the field to farm scale. 


\section{MODELS OF BIOLOGICAL PROCESSES IN GRASSLAND ECOSYSTEMS}

Understanding of processes in grassland ecosystems has been greatly assisted by the development of dynamic, mechanistic and deterministic models. For example, with a particular emphasis on grass pasture and with the objective of understanding the effect of environmental and management variables, such as stocking rate and fertiliser application, on the plant-animal-soil components of the ecosystem, the Hurley Pasture Model has been of particular value in describing the role of nitrogen and carbon in ecosystem function [29]. The focus has been on the effects of daily radiation, temperature, rainfall, relative humidity, atmospheric $\mathrm{CO}_{2}$ concentration, defoliation through harvesting and grazing animals on plant and soil $\mathrm{C}$ and $\mathrm{N}$ dynamics on a daily and seasonal basis at the scale of a homogeneous field. Other recently published models of grassland ecosystems have had objectives concerned with understanding the nitrogen, carbon and energy flows in their plant and soil components in relation to climate change and nitrogen fertilisation [11, 14, $22,30]$. However these models have their greatest role in increasing understanding of key processes and frequently they also require a large number of inputs over short time-steps.

Whilst these grassland ecosystem models can usually predict the daily biomass production of grass herbage, they do not predict the vertical distribution of the biomass of vegetation which is important in linking pasture production models to models of foraging and ingestive behaviour, as will be discussed below. There is, therefore, a need for models which predict daily biomass production and its vertical structure from a small number of easily obtainable site-specific driving variables (daily average temperature and rainfall, and soil type). There are a number of candidate models which have been built (for example that of Hutch- ings et al., submitted) to replace the solely empirically-based models that are often currently used [3]. However, these candidate models are unsatisfactory in that they do not deal with the manner in which defoliation occurs across a pasture and how this affects the horizontal structure of the vegetation as described in the paper of Marriott and Carrere in this volume [19]. Moreover, there is the need to predict the spatial distribution of species in order that models of diet selection can operate. Progress is being made in modelling mechanistically the population dynamics of legumes and grasses in grasslands [25] and in the future it should be possible to develop new and improved models which meet the requirements of predicting herbage production of grassland communities and their vertical and horizontal structure from a small number of initial inputs and driving variables. Satisfactory mechanistic models of the growth of browsed plants, namely shrubs and trees, are not available and empirical relationships in models are still widely used, and this presents a further challenge for the future when there will be an increased need to predict the impact of grazing on these plant species as extensification of ruminant production becomes a more important issue in Europe.

The need to describe the horizontal and vertical structure of the vegetation has already been highlighted because of the development of a mechanistic understanding of ingestive behaviour. Figure 2 shows how intake can be predicted from a knowledge of bite weight and bite rate, as predictors of instantaneous intake rate, and grazing time. From a knowledge of pasture structure, bite weight can be predicted from the bulk density of the grazed stratum and the bite volume which is a function of bite area and bite depth in simple grassland situations [13]. The development of relationships between bite weight and size of the grazing animal $[15,26]$ have allowed the approach to be widely applicable. Because of the amount of data collected on these variables, it is possible to use such information, together 


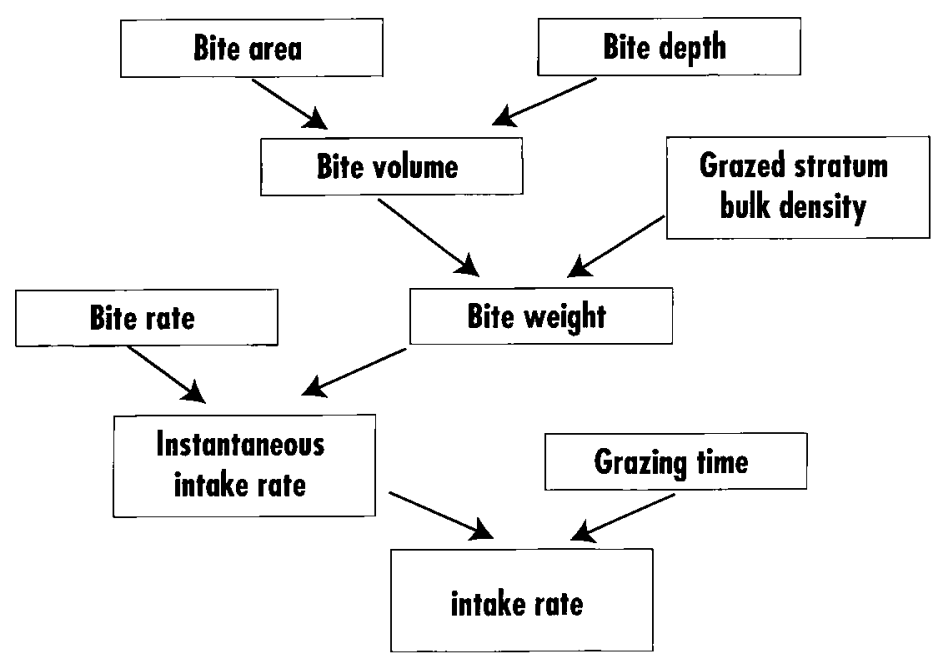

Figure 2. Description of the components of ingestive behaviour which relate sward structure to intake by large herbivores.

with information on the nutrient composition and/or digestibility of the components of plants, to predict the intake of digestible energy and available protein as inputs to an animal production model. The major weakness in such models is the prediction of grazing time. This is important because many modelling approaches assess the maximum voluntary intake that an animal can achieve as either being derived from the components of ingestive behaviour, including grazing time, or set by the physiological limits, for example associated with digesta fill or physiological stage (fatness or lactation) [4].

In many circumstances an animal is able to make choices between different structures of vegetation, plant species or plant communities, i.e., it exhibits foraging behaviour. There are a number of theories, related to optimal foraging theory and based on intake rate, which have led to the development of computer-based models of foraging; for example, the marginal value theorem [10] whose application is described in the paper of Prache et al. in this volume [24], the ideal free distribution theory [4] as well as theories based on previous experience and learning, as described by Bailey et al. in this volume [5]. Such models do not deal with all aspects of animal fitness but focus on those with a currency which allows prediction of the direct influence of the nutrition of animals on their foraging strategy. A stochastic dynamic programming procedure is one means whereby foraging and nonforaging behaviours which determine fitness can be integrated. The model of Newman et al. [21] takes this approach, and, although it is an elegant attempt, it is difficult to apply practically at present. There is much active research being conducted throughout the world on foraging theory of large herbivores and current models will be superseded in particular by more spatially explicit models, probably based on partial diffusion theory [6]. Current models which have proved to have good predictive ability are those which use digestible energy as a currency and take into account the area of each foraging type and its distribution [4].

Models which predict the output of animal products from nutrient intake are based on the UK or French feeding systems [1, 18], which are of great value in indoor feeding situations, but the model which has found most favour for grazing systems is 
the one based on the Australian feed system which was more specially designed for grazing conditions [28]. The latter system takes into account more appropriately the seasonal cyclical changes that occur in body condition in most grazing systems. Figure 3 gives a diagrammatic representation of the daily flows of energy and nitrogen during ruminant digestion that arise from the intake of organic matter and crude protein and the transformations of absorbed nutrients into animal products. This model represents 25 years of intense research but there is still a need to provide more sophisticated feedbacks to diet selection and the long-term regulation of intake.

There are few, if any, models of vegetation dynamics that can be used to predict changes in the areas of different vegetation

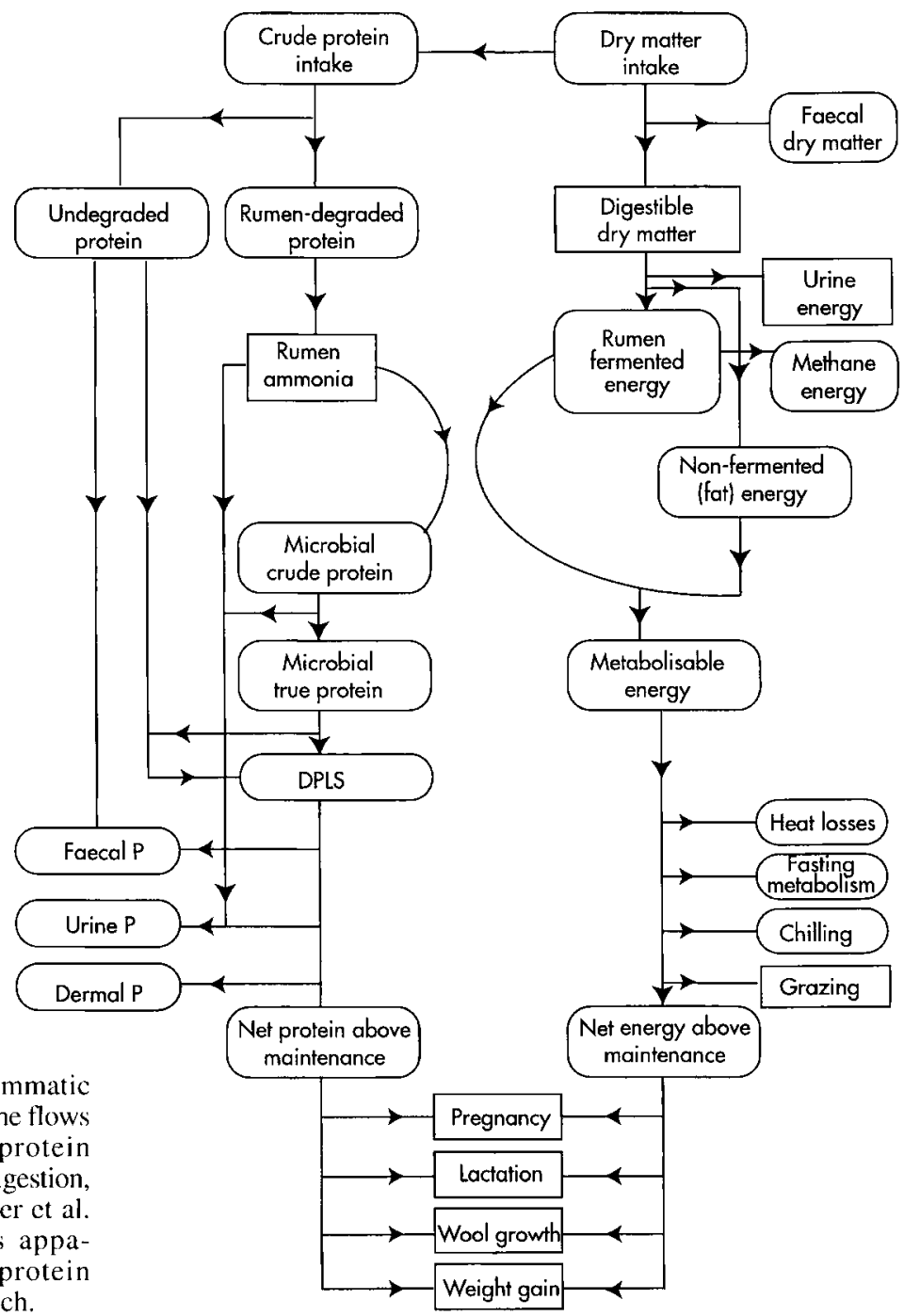

Figure 3. Diagrammatic representation of the flows of energy and protein during ruminant digestion, adapted from Freer et al. [12]. ADPLS is apparently digested protein leaving the stomach. 
types or species. Many of such changes can be caused by direct or indirect responses to grazing. Most species coexist through the outcome of species competition modified by the traits of the species in interaction with environmental and disturbance factors. Some of the unresolved issues are discussed more fully in this volume $[18,27]$. Current approaches to modelling are mainly based on our knowledge of the functional attributes of species and, because there is no widely accepted mechanistic model of the outcomes of species competition [8], a knowledgebased or expert-system approach has been advocated [2]. However, Birch et al. [7] have developed a simple mathematically explicit model based on a 3-parameter growth model for each vegetation type or species. The parameters which relate to growth are set by environmental conditions and defoliation rate, and determine the outcome of competition between species.

In this brief overview the models of components of grazing systems have been described. It can be seen that considerable advances have been made in our understanding. Is it then possible to use these models together to predict the agricultural output of a grazing system and the impact on nature conservation value?

\section{MODELS OF GRAZING SYSTEMS}

It has proved possible to aggregate a combination of process-based and empirically-based models together to produce models of grazing systems at the individual animal, field or paddock level which behave in an acceptable manner [4, 12]. They relate to conditions in the UK and Australia where sufficient research has been undertaken to allow parameterisation of the sub-models. One of the difficulties is that there are no studies where all the variables of a grazing system have been measured, including the driving variables and outputs, and hence there can be no direct testing of their accuracy of prediction. What can be done is to: 1) test the behaviour of component models against observations; 2) undertake sensitivity analysis on the principal variables in relation to a range of inputs, to check how the system behaves and how outputs are influenced; 3 ) test against what physical input/output studies are available; and 4) against expert opinion. These are the best means at present whereby such systems models can be tested in a manner that satisfies peer reviewing criteria. There have been no attempts to model in such a detailed manner the inter-relationship between grazing systems at the scale of the farm where in the UK at least there could be several grazing enterprises on the same farm.

Why would one wish to model grazing systems at the farm level? The principal reason is that decision making usually takes place at the level of the individual economic unit, which is generally that of the farm. Thus for understanding the consequences of changes in inputs or in the management of the physical resources, the farm is the most appropriate scale to consider. This applies not only to the production of economic output but also to the delivery of non-market goods (environmental and social) which may operate over a number of scales but which are strongly influenced by decisions made at the farm level. This argument applies not only to the use that can be made of such grazing models by individual actors but also to their use by government and regional policy-makers and implementers. Although policy-makers may wish to apply a policy over a region, the outcomes of that policy will be through the actions on individual farms. Moreover policy implementation can also occur at the farm-scale, for example through the production of farm plans in order to obtain agri-environmental scheme financial support. Farm-scale models have a role in developing farm plans and monitoring their efficiency in delivering policy objectives.

Such models at the farm level will have value not only to the scientist but to a number of other potential users and will be used 
more often in a predictive mode than models at the field or animal scale. These models cannot predict precisely the outcome of actions by individual actors, for example farmers have different technical and management expertise, and have to assume an average level of expertise. Moreover, they are difficult to validate other than by using expert opinion methods. However, they can be of value as decision support tools providing additional information to assist decision making. One example of such a tool is GRAZPLAN produced in Australia for sheep [12].

For those farms where grazed livestock is the predominant enterprise, which includes most of Europe's disadvantaged areas, models require to predict not only the output of animal products (sheep and cattle) but also their impact on the environment. For such models to be used, they require to operate using only a small number of easily obtained inputs and to produce outputs which are relevant and can be easily understood by the user. This requires that the potential users are involved in the development of the decision-support tools not only in setting their objectives but also in ensuring a product that will be used. This can be achieved by forming a steering group of users at the beginning of the development of a tool to help guide the project.

\section{FARM-SCALE MODELS AS DECISION-SUPPORT TOOLS}

Computer-based decision support tools are made up of a number of inter-connected modules (see figure 4). There will be a user interface which allows the user to input information, operate the tool and view the results. Making the tool modular allows interfaces to be developed which are appropriate for different users. There will also be a Database and a Database Interpreter, which store data files and allow access to them, and a Kernel and Wrapper. The Kernel holds the sub-models which are required for the farm-scale grazing model and a Wrapper which protects the model structure from being changed and which communicates with the database interpreter.

As an example of the development of a computer-based decision support tool, a brief description will be now be given of the structure of a decision support tool, called HILLPLAN, which, although being

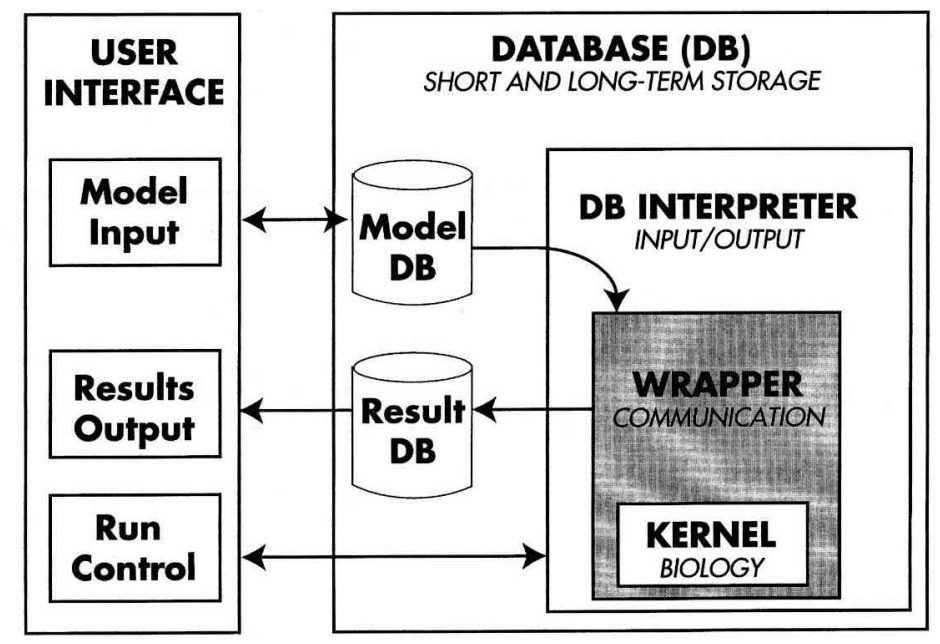

Figure 4. Diagram of a typical design of a decision-support system. 
developed for a particular application, has been designed in a generic manner to allow it to be adapted for any set of grazing resources. A brief description has been given in Milne et al. [20]. The particular application is to aid the implementation of the Countryside Premium Scheme in Scotland by the Scottish Office Agriculture, Fisheries and Environment Department (SOAEFD). This scheme aims to provide environmental benefits at the farm level. One component of the scheme is to protect the biodiversity of the grass and heath plant communities on farms by adopting a suitable grazing management plan. Hence a model to predict changes in the proportion of different vegetation communities as a consequence of grazing is important. The other main output of HILLPLAN is the animal production from flocks of sheep and herds of cattle grazing on the farm in order to allow an assessment of the economic consequences of implementing the plan.

HILLPLAN has an internal structure ( $\mathrm{fig}$ ure 5) which allows for a farm, or more generically a Land Management Area (LMA), to have any number of flocks or herds as enterprises (the economic sub-unit) which can graze on any field, or more gener- ically a land management unit (LMU). Within an LMU, there can be any number of patches of vegetation (vegetation patch) which themselves can contain any number of plant species (vegetation type). The seasonal growth of the grass vegetation types and the impact of defoliation on their growth is based on a partly empirical and partly mechanistic model, derived from the model of Hutchings et al. (submitted), which can grow tall and short patches depending on the defoliation pattern. The model requires inputs on climate, soils and fertiliser levels and operates on a daily time step. The growth of shrub vegetation types is modelled empirically, because there are no appropriate mechanistic models available. The flocks of sheep and herds of cattle can be divided into age and productivity classes and within each of these classes individual animals are modelled. The foraging behaviour model which is based on a modified ideal free distribution model, which has been found to behave well in a previous grazing systems model [4] operates both at the vegetation patch and vegetation type levels and uses information on the mechanics of grazing to predict instantaneous intake rates. The resulting intakes of metabolis-

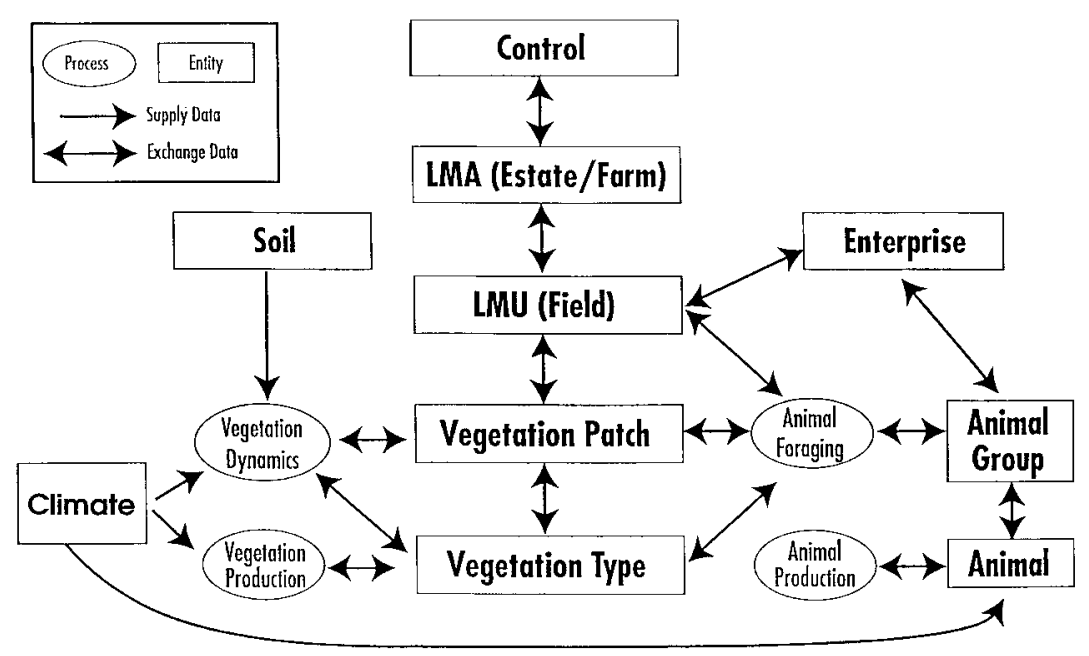

Figure 5. Diagrammatic representation of structure of the kernel of HILLPLAN. 
able energy and protein are then used to predict the amount of animal output produced on a daily basis using a modified livestock feeding standards model [28]. The longterm effects of grazing on the proportion of plant species in a vegetation patch is predicted on an annual basis, using a new model of Birch et al. [7] specifically developed for this purpose. Farmers make planning and scheduling decisions on when to mate their animals, when to sell them, when to move them from one field to another, when to give supplementary feeding and when to house them. The model has been designed to allow this information to be incorporated and applied.

In the particular application described above, inputs required must be kept to a minimum such that they can be collected from a half-day visit to a farm. They include the area and number of each LMU and the composition, area and number of patches in each LMU, the number of animals in each flock or herd, their location on LMUs at any time of the year and date of mating. There is a large number of outputs that can be generated and these can be adjusted to suit the application of HILLPLAN. In the particular
SOAEFD application the most important output was that which relates to the vegetation communities

HILLPLAN can provide valuable insights into the way that the land and other resources of farms can be allocated in a tactical manner in relation to animal production and the delivery of some environmental goods. HILLPLAN provides decision support specifically for grazing enterprises based upon sown, natural and semi-natural vegetation. Most farms in the upland areas of Scotland are composed of more than one enterprise and may also include sheep and cattle systems based upon sown pastures and some arable crops. In addition many farms include areas of woodland. A modelbased land allocation decision support system (called LADSS) is also being developed to support strategic decision making at the farm level.

LADSS [9] consists of a geographic information system (Smallworld) and a knowledge-based system (Gensym G2), as shown in figure 6. It is object-oriented, like HILLPLAN, and contains spatially explicit information on, for example, soils, land cover and topography about a farm. The

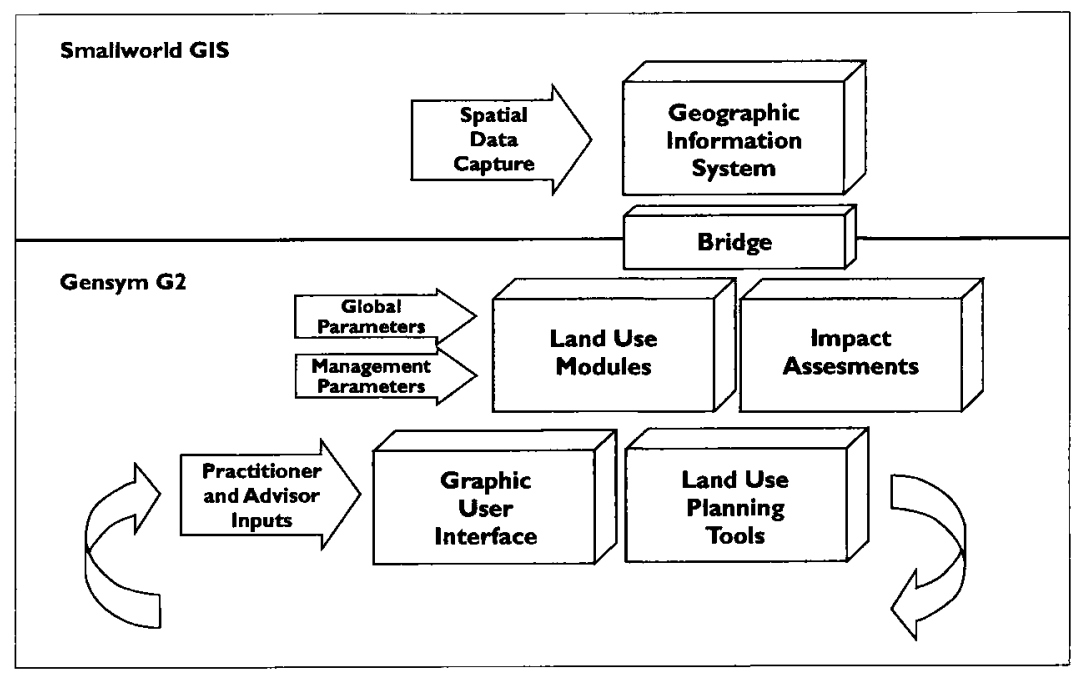

Figure 6. Diagrammatic representation of components of LADSS. 
knowledge-based system contains, within the land use modules, models of sheep and cattle grazing enterprises, barley cropping and deciduous and conifer woodland systems and within the impact assessment section impacts on farm finances, biodiversity and landscape. Global and management parameters, for example fertiliser costs and amounts of fertiliser applied, are specified by the user. Using the resource data and the enterprise models together with priorities placed on land allocation to enterprises by the land manager, LADSS allocates each field to a land use enterprise based on land suitability criteria. It finds patterns of land use which most closely match the requirements of the land manager in terms of economic, environmental and social impacts. Currently the impacts are mainly economic but outputs in terms of environmental impact assessments, based upon landscape ecology measures, and social impacts, based in the first place upon the labour requirements of the land use pattern are being developed. The outputs of field allocations and other information of this strategic planning tool are presented using the Geographic Information System.

\section{CONCLUSION}

Tools, such as HILLPLAN and LADSS, provide test-beds for researchers to explore implications for rural land use. For example they allow the examination of policy scenarios for achieving nature conservation objectives and their impact on farm incomes. They also play an important role in technology transfer as a means of conveying complex information to farmers, and regional and government departments, and hence aid the process of decision-making by these sectors. There are a number of challenges that remain. Methods of validation, particularly in spatial models, need to be developed. Confidence limits on the outputs from such tools required to be included. The development of farmer typologies may be valuable in exploring how to depict variations in management skills. Finally, design of such tools will need to ensure that they are easy to use and interpret if they are to be widely taken up.

\section{REFERENCES}

[1] Agricultural Research Council, The Nutrient Requirements of Ruminant Livestock, CAB, Farnham Royal, UK, 1980.

[2] Armstrong H.M., Milne J.A., The effects of grazing on vegetation species composition, in: Thompson D.B.A., Hester A.J., Ushe M.B. (Eds.), Heaths and Moorlands, Cultural Landscapes, HMSO, Edinburgh, 1995, pp. 162-173.

[3] Armstrong H.M., Gordon I.J., Grant S.A, Hutchings M.J., Milne J.A., Sibbald A.R., A model of the grazing of hill vegetation by sheep in the UK. 1. The prediction of vegetation biomass, J. Appl. Ecol. 34 (1997) 166-185.

[4] Armstrong H. M., Gordon I.J., Grant S.A.., Hutchings N.J., Illius A.W., Milne J.A., Sibbald A.R., A model of the grazing of hill vegetation by sheep in the UK. 2. The prediction of intake by sheep, J. Appl. Ecol. 34 (1997) 186-206.

[5] Bailey D., Dumont B., Wallis de Vries M.F., Utilisation of heterogeneous grasslands by domestic herbivores: theory to management, Ann. Zootech. 47 (1998) 321-333.

[6] Beecham J.R., Farnsworth K.D., Animal foraging from an individual perspective - an objectoriented model, Ecol. Model, (1998), in press.

[7] Birch C.P.D., Werkman B.R., Partridge L.W., A predictive model of vegetation dynamics under grazing, Proc. 18th Int. Grass. Congr., 1997, pp. 12.5-12.6.

[8] Bullock J.M., Plant competition and population dynamics, in: Hodgson J., Illius A.W. (Eds.), The ecology and management of grazing systems, CAB International, Wallingford, UK, 1996, pp. 69-100.

[9] Butcher C.S., Matthews K.B., Sibbald A.R., The implementation of a spatial land allocation decision support system for upland farms in Scotland, Proc. 4th European Society for Agronomy Congress, 1996, pp. 416-417.

[10] Charnov E.L., Optimal foraging, the marginal theorem, Theor. Pop. Biol. 9 (1976) 129-136.

[ I ] Chen D-X., Coughenour M.B., GEMTM - a general model for energy and mass transfer of land surfaces and its application at the FIFE sites, Agricult. Forest Meteor. 68 (1994) 145-171.

[12] Freer M., Moore A.D., Donnelly J.R., Grazplan: decision support systems for Australian grazing enterprises. 2 . The animal biology model for feed intake, production and reproduction and the Grazfeed DSS, Agric. Syst. 46 (1997). 
[13] Hodgson J., The control of herbage intake in the grazing ruminant, Proc. Nutr. Soc. 44 (1985) $339-346$.

[14] Hunt H.W., Trlica M.J., Redente E.F., Moore J.C., Detling J.K., Kittel T.G.F., Walter D.E., Fowler M.C., Klein D.A.,Elliot E.T., Simulation model for the effects of climate change on temperate grassland ecosystems, Ecol. Model. 53 (1991) 205-246.

[15] Illius A.W., Gordon I.J., The allometry of food intake in grazing ruminants, J. Anim. Ecol. 56 (1987) $989-999$.

[16] Illius A.W., Hodgson J., Progress in understanding of ecology and management of grazing systems, in: Hodgson J., Illius A.W. (Eds.), The ecology and management of grazing systems, CAB International, Wallingford, UK, 1996, p. 429 .

[17] Inra, Alimentation des bovins, ovins et caprins, Institut National de la Recherche Agronomique, Paris, 1988.

[18] Loiseau P., Loualt F., L'Homme G., Gestion des écosystèmes pâturés en situations extensives : Apports de l'écologie fonctionnelle et perspectives de recherches appliquées en moyenne montagne humide, Ann. Zootech. 47 (1998) 395-406.

[19] Marriott C.A., Carrere P., Structure and dynamics of grazed vegetation. Ann, Zootech. 47 (1998) 359-369.

[20] Milne J.A., Sibbald A.R., Farnsworth K.D., Birch C.P.D., HILLPLAN - a decision support tool for predicting the impact of grazing ruminants on animal production and vegetation changes in temperate grasslands and rangelands. The Earth's Changing Land, GCTE-LUCC Open Science Conference on Global Change, 1998, pp. 141-142.

[21] Newman J.A., Parsons A.J., Thornley J.H.M., Penning P.D., Krebs J.R., Optimal diet selection by a generalist grazing herbivore, Funct. Ecol. 9 (1995) 255-268.
[22] Parton W.J., Scurlock J.M.O., Ojima D.S., Gilmanov T.G., Scoles R.J., Schimel D.S., Kirchner T., Menaut J-C., Seastedt T., Garcia Moya E., Apinan Kamnaral Kinyamario J.I., Observations and modelling of biomass and soil organic matter dynamics for the grassland biome worldwide, Global Biogeochem. Cycles 7 (1993) 785-809

[23] Pearson C.J., Ison R.L., The Agronomy of Grassland Systems, Cambridge University Press, Cambridge, UK, 1997.

[24] Prache S., Gordon I.J., Rook A.J., Foraging behaviour and diet selection in domestic herbivores, Ann. Zootech. 47 (1998) 335-345.

[25] Schwinning S., Parsons A.J., A spatially explicit population model of stoloniferous $\mathrm{N}$-fixing legumes in mixed pasture with grass, J. Ecol. 84 (1996) 815-826.

[26] Shipley L.A., Gross J.E., Spalinger D.E., Hobbs N.T., Wunder, B.A., The scaling of intake rate in mammalian herbivores, Am. Nat. 143 (1994) 1055-1082.

[27] Sousanna J-F., Lafarge M., Competition for resources between neighbouring species and patch scale vegetation dynamics in temperate grasslands, Ann. Zootech. 47 (1998) 371-382.

[28] Standing Committee on Agriculture, Feeding standards for Australian livestock: ruminants, CSIRO Australia, Melbourne, 1990.

[29] Thornley J.H.M., Grassland Dynamics, an ecosystem simulation model, CAB International, 1998.

[30] Verberne E., Simulation of the nitrogen and water balance in a system of grassland and soil, Nota 258. DLO-Institut voor Bodemvruchtbaarheid, Haren, the Netherlands, 1990. 